\title{
Namık Kemal Üniversitesi Araştırma ve Uygulama Hastanesi'ne başvuran çocuklarda idrar örneklerinden izole edilen etkenler ve antibiyotik direnç durumları
}

\author{
Agents isolated from urine samples of children attended the Namik Kemal \\ University Research and Practice Hospital and the rate of antibiotic resistance
}

Hayati Güneş*, Mustafa Metin Donma, Burçin Nalbantoğlu, Mine Aydın, Ayşe Demet Kaya, Birol Topçu

Tıbbi Mikrobiyoloji Anabilim Dalı (Yrd. Doç. Dr. H. Güneş, Arş. Gör. M. Aydın, Prof. Dr. A. D. Kaya), Çocuk Sağlı̆̆ı ve Hastalıkları Anabilim Dalı (Prof. Dr. M. M. Donma, Yrd. Doç. Dr. B. Nalbantoğlu), Biyoistatistik ve Tıbbi Bilişism Anabilim Dalı (Yrd. Doç. Dr. B. Topçu), Namık Kemal Üniversitesi Tıp Fakültesi, TR-59100 Tekirdağ

\section{Özet}

Amaç. İdrar yolu enfeksiyonları, çocukluk çağında sık görülen enfeksiyonlardandır. Antibiyotiklerin yaygın kullanımı ile beraber bakterilerdeki antibiyotik direnci ciddi bir sorun haline gelmiştir. Çalışmamızda bölgemizde çocukluk yaş grubundaki hastalarda idrar kültürlerinde üreyen bakteriler ve antibiyotik direnç oranlarının araştırılması amaçlanmıştır. Yöntemler. Namık Kemal üniversitesi Araştırma ve Uygulama Hastanesi'ne başvuran çocukluk yaş grubundaki hastaların idrar örnekleri kanlı ve eozin metilen blue besiyerlerine ekilmiştir. Üreyen bakteriler konvansiyonel ve/veya yarı otomatik testlerle tanımlanmış ve CLSI'nin önerileri doğrultusunda antibiyotik direnç oranları belirlenmiştir. Bulgular. Gönderilen toplam 1003 idrar örneğinin 127 $(\% 12,7)$ 'sinde üreme gözlenmiştir. Üreyen bakteri sayı ve oranları: Escherichia coli: $66(\% 52,0)$, koagülaz negatif stafilokoklar: 14 (\%11,0), Enterococcus spp: 14 (\%11,0), Proteus spp: $10(\% 7,9)$, Citrobacter spp:7(\%5,5), Klebsiella spp $7(\% 5,5)$, Pseudomonas spp 6(\%4,7) ve Enterobacter spp:1(\%0,8) MRSA: $1(\% 0,8)$, Enterobacter spp: $1(\% 0,8)$ ve Morganella morganii: $1(\% 0,8)$ 'dir. İzole edilen Gram negatif bakterilerde en yüksek direnç oranı ampisiline karşı $(\% 65,2)$ bulunmuştur. Koagülaz negatif stafilokoklarda ve enterokoklarda ise en yüksek direnç oranı ise eritromisine (sırasıyla \%64,3 ve \%85,7 oranlarında) karşı bulunmuştur. Sonuç. Çalışma sonuçlarımız, Gram negatif bakterilerin etken olduğu enfeksiyonlarda imipenem ve amikasin, oral preparatlardan nitrofurantoin ve amoksisilin/klavulanatın; Gram pozitif bakterilerin etken olduğu enfeksiyonlarda ise teikoplanin ve linezolid'in tedavide seçilebilecek ajanlar olduğunu ortaya koymaktadır. Bölgesel antibiyotik direnç oranları konusunda bilgi sahibi olunması ile ampirik antibiyotik kullanımında, uygun antibiyotik seçimi sağlanacak ve bu sayede ortaya çıkacak olan tedavi sorunları, mali yük ve antimikrobiyal direnç gelişimi gibi problemler engellenecektir.

Anahtar sözcükler: Üriner kanal enfeksiyonları, ilaç direnci, mikrobiyal, çocuk

\begin{abstract}
Aim. Urinary tract infections are the most common infections in childhood. Antimicrobial resistance has become a serious problem as a result of extensive antibiotic comsumption. In this study determining the bacteria grown in urine cultures of children and antimicrobial resistance rates in our region, was aimed. Methods. Urine samples of children who attended the Namık Kemal University Research and Practice Hospital were inoculated blood and eozin metilen blue agar plates. Isolates were identified by conventional and/or semi automated methods and antibiotic resistance rates were determined according to the recommendations of CLSI. Results. Of the 1003 samples sent, growth was obtained in 127(12.7\%).The isolates were as follows; Escherichia coli: $66(52.0 \%)$, coagulase negative staphyococci: 14 (11.0\%), Enterococcus spp: 14 11.0(\%), Proteus spp: 10 7.9(\%), Citrobacter spp:7(5.5\%), Klebsiella spp 7 (5,5\%), Pseudomonas spp 6(4.7\%), Enterobacter spp:1(0.8\%) MRSA: 1 0.8(\%), and Morganella morganii: $1(0.8 \%)$. The highest resistance rates of Gram negative bacteria had higher resistant to ampicilin (65.2\%). Coagulase
\end{abstract}


negative staphylococci and enterococci had higher resistant to erithromycine (respectively $64.3 \%$, and $85.7 \%$ ). Conclusion. The results of our study showed that, in infections caused by Gram negative bacteria imipenem and amikacin, from oral preparats nitrofurantoin and amoksisilin/clavulanate and in infections caused by Gram positive bacteria teichoplanin and linezolide are the agents that can be used in therapy. Knowledge of the regional resistance patterns can lead the selection of appropriate antibiotic in empiric therapy and as a result of this, management problems, financial problems and the development of antimicrobial resistance can be prevented.

Keywords: Urinary tract infections, drug resistance, microbial, child

Geliş tarihi/Received: 30 Temmuz 2012; Kabul tarihi/Accepted: 04 Şubat 2013

\section{*Iletişim adresi:}

Dr. Hayati Güneş, Tıbbi Mikrobiyoloji Anabilim Dalı, Namık Kemal Üniversitesi Tıp Fakültesi, TR-59100 Tekirdağ. E-posta: dr_hgunes@yahoo.com

\section{Giriș}

Üriner sistem enfeksiyonları, çocukluk döneminde (özellikle 2 yaş altı çocuklarda) çok sik rastlanan bakteriyel enfeksiyonlardır. Sikl1k olarak solunum sistemi enfeksiyonlarından sonra ikinci sırada yer alırlar [1-2]. Bu enfeksiyonlar, genelde iyi seyretmekle birlikte bazen renal skar sonucunda kronik böbrek yetmezliğine yol açabilirler [3]. Ülkemizde böbrek yetmezliği yapan nedenler içinde üriner sistem enfeksiyonları ve reflü nefropatisi ilk sırayı almaktadır [4].

Üriner sistem enfeksiyonlarına tüm yaş gruplarında enterik kökenli bakteriler ve sıklıkla Escherichia coli (E.coli) etkendir [5]. Tekrarlayan ya da altta yatan üriner sistem patolojisinin varlığında üriner sistem enfeksiyonunda E.coli dışında diğer Gram negatif ve pozitif ajanlar da önem kazanmaktadır.

Üriner sistem enfeksiyonları şüphesi olan tüm hastalarda ampirik uygun antibiyotik tedavisi morbidite oranını azalttığı için önerilmektedir. Ancak uygun olmayan antibiyotiklerin seçimi tedavi etkinliğinin azalmasına ve yukarıda belirtilen ileri dönem komplikasyonlarına yol açabilmektedir [6-8]. Antibiyotikler kullanılmaya başlandığından beri yaygın ve hatalı kullanım, direncin önemli bir problem haline gelmesine neden olmuştur. Direnç gelişiminde ilaçların uygun olmayan doz ve sürelerde kullanılması, etki spektrumlarına dikkat edilmeyişi, sık tekrarlayan idrar yolu enfeksiyonlarının varlığı, daha önce hastaneye yatış öyküsü ve profilaktik olarak geniş spektrumlu antibiyotiklerin verilmesi önemli rol oynamaktadır [9-10]. Bilindiği gibi üriner sistem enfeksiyonu tanısında altın standart, antibiyotik tedavisine başlamadan önce alınan idrar kültürü örneğidir [11]. Bu yüzden idrar kültürü sonuçları mutlaka dikkate alınmalı ve kullanılması düşünülen ampirik antibiyotiklere karar verilirken bölgesel bakteri direnç paternleri göz önünde bulundurulmalıdır [12].

$\mathrm{Bu}$ çalışmada çocukluk yaş grubunda üriner sistem enfeksiyonu şüphesi taşıyan hastalardan gönderilen idrar kültürlerinin sonuçları ve üreyen bakterilerin antibiyotik direnç paternlerinin değerlendirilmesi amaçlanmıştır.

\section{Gereç ve yöntem}

Çalışmada Şubat 2010-Mart 2012 tarihleri arasında Namık Kemal Üniversitesi Araştırma ve Uygulama Hastanesi'ne başvuran çocukluk yaş grubundaki hastaların idrar kültürü sonuçları retrospektif olarak incelenmiştir. Hastalar; yaş grubu olarak 2 yaş altı, 2-6 arası ve 6 yaş üzeri olmak üzere 3 gruba bölünmüş ve her yaş grubunda üreme ve kontaminasyon oranları belirlenerek birbirleriyle karşılaştırılmıştır.

İştahsızlık, huzursuzluk, ateş, kusma, karın ağrısı, kilo alamama, dizüri, pollaküri, enürezis ve idrar renginde değişiklik gibi semptomatik üriner sistem enfeksiyonu 
yakınmaları olan hastaların idrar örnekleri; idrar kontrolü olan hastalarda standart temizliği takiben orta akım idrarı, idrar kontrolü olmayanlarda ise yine standart temizliği takiben steril idrar torbası ile alınmıştır. Kültür için alınan tüm idrar örnekleri \%5 koyun kanlı agar ve eozin metilen blue (EMB) besiyerlerine $0,001 \mathrm{~mL}$ inoküle edilmiştir. Etüvde $37^{\circ} \mathrm{C}$ 'de $18-24$ saat inkübasyondan sonra kültürlerde, $10^{5}$ koloni $(\mathrm{CFU} / \mathrm{mL})$ ve üzerinde tek bakteri üremesi pozitif kriter olarak kabul edilmiştir. İki ve üzeri farklı bakteri üremesi kontaminasyon olarak değerlendirilmiştir. Böyle durumlarda idrar kültürleri tekrar edilmiş, daha önceden üreyenlerle aynı bakterilerin ürediği durumlar miks enfeksiyon olarak kabul edilmiş ve her 2 bakteri için de ayrı ayrı identifikasyon ve antibiyotik duyarlılık testi yapılmıştır. Gram pozitif bakterilerin identifikasyonu katalaz, koagülaz, eskülin hidrolizi, \%6,5'lik NaCl'li besiyerinde üreyebilme ve PYR testleriyle, bu testlerle kesin sonuca varılamadığında BBL Crystal Gram Positive ID (Beckton Dickinson, ABD) kitiyle; Gram negatif bakterilerde ise konvansiyonel biyokimyasal testler, bunlarla bir sonuca varılamadığında ise BBL Crystal enteric/Nonfermenter ID (Beckton Dickinson, ABD) kitiyle yapılmıştır.

Antibiyotik duyarlılığı Müller-Hinton agarda disk diffüzyon yöntemi ile CLSI'nin önerileri doğrultusunda değerlendirilmiştir [13]. Enterobacteriaceae grubu bakterilerde amikasin, amoksisilin-klavulanik asit, ampisilin, ampisilin-sulbaktam, seftazidim, seftriakson, sefuroksim, gentamisin, imipenem ve trimetoprim-sulfametoksazol ve nitrofurantoin; stafilokoklarda klindamisin, eritromisin, gentamisin, linezolid, teikoplanin, trimetoprim-sulfametoksazol, vankomisin ve metisilin; enterokoklarda eritromisin, yüksek düzey gentamisin, linezolid, teikoplanin, vankomisin, ampisilin ve penisilin; psödomonaslarda ise amikasin, sefepim, seftazidim, gentamisin, imipenem, meropenem, ve piperasilin-tazobaktama direnç oranları belirlenmiştir. Kontrol için E. coli ATCC 25922 ve Staphylococcus aureus (S. aureus) ATCC 25923 suşları kullanılmıştır.

Çalışmada hastalar cinsiyetlerine göre de ayrılarak üreme oranları belirlenmiş ve bu 2 grup birbiriyle karşılaştırılmıştır. Bu oranların karşılaş̧ııılmalarında Ki-kare testi uygulanmış ve sonuçlar yorumlanmıştır. İstatistiksel çalışmalarda, SPSS 18.0 istatistik paket programı kullanılmış ve 0.05 'in altındaki p değerleri anlamlı olarak kabul edilmiştir.

\section{Bulgular}

Şubat 2010-Mart 2012 tarihleri arasında Namık Kemal Üniversitesi Araştırma ve Uygulama Hastanesi Mikrobiyoloji laboratuvarına, çocuk yaş grubu hastalardan toplam 1003 adet idrar numunesi gönderilmiştir. Numunelerin 692'si (\%69) k1z, 311'i (\%31) erkek hastalardan gönderilmiştir. Hastaların yaş aralığ 1 ay-17,5 yaş olup, ortalamaları $6,57 \pm 3,83$ olarak hesaplanmıştır. İki yaş altı hasta grubu 151, 2-6 yaş arası grup 312 ve 6 yaş üzeri grup da 540 kişiden oluşmuştur.

$\mathrm{Bu}$ numunelerden yapılan kültürlerin 654 ünde $(\% 65,2)$ üreme olmamış, 127'sinde $(\% 12,7)$ etken mikroorganizma üremiş ve 222 'si de $(\% 22,1)$ kontaminasyon olarak değerlendirilmiştir. Üreyen bakterilerden 98 tanesi $(\% 77,2)$ Gram negatif bakterilerden, 29 'u $(\% 22,8)$ da Gram pozitiflerden oluşmuşstur. En sik izole edilen bakteri E. coli olmuştur $(\% 52,0)$.

Cinsiyetlere göre üreme oranları dikkate alındığında kızlardan gönderilen 692 numuneden 89'unda (\%12,9), erkeklerden gönderilen 311 numuneden 38'inde $(\% 12,2)$ üreme görülmüştür. Yaşlara göre üreme oranları değerlendirildiğinde, 1. grupta $29(\% 19,2) 2$. grupta $39(\% 12,5), 3$. grupta ise 59 hastada $(\% 10,9)$ etken mikroorganizma üremiştir. Üreyen bakterilerin sayı ve oranları Tablo-1'de gösterilmiştir. 
Tablo 1. İdrar kültürlerinde üreyen etkenler ve yüzde oranları.

\begin{tabular}{lll}
\hline Bakteri & n & $\%$ \\
\hline Escherichia coli & 66 & 52,0 \\
Enterococcus spp. & 14 & 11,0 \\
\hline Koagülaz Negatif Stafilokok & 14 & 11,0 \\
\hline Citrobacter spp. & 7 & 5,5 \\
Pseudomonas spp. & 6 & 4,7 \\
Klebsiella spp. & 7 & 5,5 \\
Proteus spp & 10 & 7,9 \\
\hline MRSA & 1 & 0,8 \\
\hline Morganella morganii & 1 & 0,8 \\
\hline Enterobacter spp & 1 & 0,8 \\
\hline
\end{tabular}

Enterobacteriaceae grubu Gram negatif bakterilerin antibiyotik direnç profilleri Tablo2 'de sunulmuştur. Diğer Gram negatif bakterilerden psödomonaslarda bir suş $(\% 16,7)$ gentamisine dirençli olarak saptanmış, diğer antibiyotiklere dirence rastlanmamıştır. Gram pozitif bakterilerden metisiline dirençli S. aureus (MRSA), oksasilin dışındaki ilaçlara duyarlı bulunmuştur. Diğer Gram pozitif bakteriler olan koagülaz negatif stafilokoklar (KNS) ve enterokokların antibiyotik direnç profilleri Tablo 3'te sunulmuştur.

Tablo 2. Enterobacteriaceae grubu bakterilerin antibiyotik direnç sayı ve oranları (\%).

\begin{tabular}{lllllll}
\hline Antibiyotik & $\begin{array}{l}\text { E. Coli } \\
(\mathbf{n = 6 6 )}\end{array}$ & $\begin{array}{l}\text { Citrobacter } \\
(\mathbf{n = 7})\end{array}$ & $\begin{array}{l}\text { Proteus } \\
(\mathbf{n = 1 0})\end{array}$ & $\begin{array}{l}\text { Klebsiella spp. } \\
(\mathbf{n = 7})\end{array}$ & $\begin{array}{l}\text { Diğer* } \\
(\mathbf{n = 2})\end{array}$ & $\begin{array}{l}\text { Toplam } \\
(\mathbf{n}: \mathbf{9 2})\end{array}$ \\
\hline Amikasin & $5(7,6)$ & $0(0)$ & $2(20)$ & $0(0)$ & $0(0)$ & $7(7,6)$ \\
Amoks/Klav & $21(31,8)$ & $2(28,6)$ & $3(30)$ & $2(28,6)$ & $1(50)$ & $29(31,5)$ \\
Ampisilin & $40(60,6)$ & $7(100)$ & $5(50)$ & $6(85,7)$ & $2(100)$ & $60(65,2)$ \\
Amp/Sulb & $32(48,5)$ & $2(28,6)$ & $5(50)$ & $2(28,6)$ & $1(50)$ & $42(45,7)$ \\
Seftazidim & $22(33,3)$ & $3(42,9)$ & $1(10)$ & $1(14,3)$ & $0(0)$ & $27(29,3)$ \\
Seftriakson & $18(27,3)$ & $1(14,3)$ & $0(0)$ & $2(28,6)$ & $1(50)$ & $22(23,9)$ \\
Sefuroksim & $26(39,4)$ & $2(28,6)$ & $5(50)$ & $2(28,6)$ & $1(50)$ & $36(39,1)$ \\
Gentamisin & $14(21,2)$ & $2(28,6)$ & $3(30)$ & $0(0)$ & $0(0)$ & $19(20,7)$ \\
Imipenem & $0(0)$ & $0(0)$ & $0(0)$ & $0(0)$ & $0(0)$ & $0(0)$ \\
Trim/Sulf & $32(48,5)$ & $5(71,4)$ & $3(30)$ & $1(14,3)$ & $0(0)$ & $41(44,6)$ \\
Nitrofurantoin & $2(3,0)$ & $2(28,6)$ & $6(30)$ & $0(0)$ & $0(0)$ & $10(10,9)$ \\
\hline
\end{tabular}

Tablo 3. Koagülaz Negatif Stafilokok ve enterokoklarda antibiyotik direnç sayı ve oranları $(\%)$.

\begin{tabular}{lll}
\hline Antibiyotik & KNS (n=14) & Enterokok (n=14) \\
\hline Klindamisin & $3(21,4)$ & - \\
Eritromisin & $9(64,3)$ & $12(85,7)$ \\
Gentamisin & $3(21,4)$ & - \\
Linezolid & $0(0)$ & $0(0)$ \\
Teikoplanin & $0(0)$ & $0(0)$ \\
Trimetoprim/Sulfometoksazol & $2(14,3)$ & - \\
Vankomisin & $0(0)$ & $2(14,3)$ \\
Yüksek Düzey Gentamisin & - & $3(21,4)$ \\
Ampisilin & - & $3(21,4)$ \\
Penisilin & - & $11(78,6)$ \\
Metisilin & $9(64,3)$ & - \\
\hline KNS: Koagülaz negatif stafilokok. & \\
\hline
\end{tabular}




\section{Tartışma}

Üriner sistem enfeksiyonları, sık görülen ve antibiyotiklerin en sik kullanıldığ 1 enfeksiyonlar olmalarından dolayı önemlidir [14-15]. Çalışmamızda numunelerin \%69'u kız hastalardan gönderilmiştir. Üreme oranı olarak da kızlarla erkekler arasında istatistiksel açıdan anlamlı bir fark bulunmaktadır. Bunun nedeni de kızlarda üretranın anatomik yapısından dolayı bakteri kolonizasyonuna daha yatkın oluşu ve bağırsak florası ile daha kolay kontamine olabilmesidir. Kız çocuklarında perine temizliğinin uygun yapılmaması enfeksiyonların sık tekrarlamasına ve buna bağlı olarak morbiditenin artmasına yol açmaktadır [16]. Annelere perine temizliğinin önden arkaya doğru yapılmasının gerekliliği anlatılarak enfeksiyon oranları düşürülebilir.

Çalışmamızda yaş arttıkça üreme oranlarında istatistiksel olarak anlamlı derecede düşüş görülmektedir. Yine 1. grupta $64,(\% 42,4), 2$. grupta $70,(\% 22,4), 3$. grupta ise 88 örnekte $(\% 16,3)$ kontaminasyon tespit edilmiştir. Gruplar arasındaki fark istatistiksel açıdan anlamlı bulunmuştur. Bu fark; çocuk büyüdükçe hem immün sistemin gelişmesi, hem de tuvalet alışkanlığ kontaminasyonun azalmasından kaynaklanmaktadır.

Çalışmada, en sık izole edilen mikroorganizma E.coli (\%52), olarak tespit edilmiştir. Yaş gruplarına göre üreyen bakteri oranlarına bakıldığında tüm gruplarda en yüksek üreme oranı da E. coli'ye aittir (Sirasıyla \%34,5, 48,7 62,7). Birinci grupta koagülaz negatif stafilokoklar (KNS) ve psödomonaslar \%13,8 oranında; 2 . grupta proteus $\% 17,9$, KNS $\% 12,8$ oranında; 3. grupta ise enterokoklar \%15,3 ve KNS \%8,5 oranında üremiştir. E. coli dışındaki ajanların yaş gruplarına göre sıklığı değişmekle beraber, bu etkenlerin KNS, enterokok ve Gram negatif basiller olduğu görülmektedir. Etkenlerin dağılımı literatürle uyumlu bulunmuş̧tur [17-21].

Etken patojenlerin sık kullanılan antibiyotiklere gittikçe artan direnci ciddi problem oluşturmaya başlamıştır. Bundan dolayı dikkatli bir sürveyans çalışmasıyla pediatrik yaş grubu enfeksiyonlarından izole edilen mikroorganizmaların bölgesel antibiyotik direnç paternlerinin belirlenmesi ve tedavinin bu veriler 1şığında planlanması, gelecekte görülebilecek dirençli enfeksiyonların azalmasını ve bunlara bağlı mortalitenin de azalmasını sağlayacaktır. E. coli suşlarına etkinliği en yüksek antibiyotikler imipenem (\% $100)$, amikasin $(\% 95)$ ve gentamisin $(\% 78,8)$ olarak bulunmuştur.

Pediatrik yaş grubunda ampirik tedavide oral preperatlar tercih edilmekte ve özellikle beta laktam-beta laktamaz inhibitörü kombinasyonu içeren antibiyotikler kullanılmaktadır. Bu çalışmada Gram negatif bakterilerden özelde E. coli'nin, genel olarak bakıldığında da tüm bakterilerin üriner sistem enfeksiyonlarında ampirik olarak sık tercih edilen oral antibiyotikler olan ampisilin, ampisilin-sulbaktam ve trimetoprimsulfometoksazole karşı direnç oranlarının yüksek olduğu görülmüştür. Bu yüksek oranlar, adı geçen antibiyotiklerin artık bir seçenek olmaktan çıktığını göstermektedir. Üstün ve ark. [22], Geçit ve ark [23], Tekin ve ark [24] çalışmalarında benzer sonuçlar elde etmişlerdir. Oral olarak kullanılan antibiyotiklerden direnç oranı nisbeten daha düşük bulunan ilaç amoksisilin-klavulanattır $(\% 31,8)$.

İkinci kuşak sefalosporinler etki spektrumlarının uygunluğu ve yan etkilerinin nisbeten az olması nedeniyle üriner sistem enfeksiyonlarında s1k kullanılan antibiyotik gruplarındandır. Bu grup ilaçlara karşı direnç gelişimi çok yüksek olmadığından rutin tedavide yaygın olarak kullanılırlar $[25,26]$. Yapılan bazı çalışmalarda sefuroksim direnci $\% 7$ ve \%10 gibi düşük değerlerde bulunurken [17, 27] \%26 [28] veya \%38,2 [29] gibi yüksek direnç oranlarını bildirenler de vardır. Bizim çalışmamızda bu oran \%39'larla bu değerlerin üstünde olarak tespit edilmiştir. Bunun sebebi sefuroksimin oral formunun bulunması ve sik tercih edilmesi olabilir. 
Aminoglikozidler, idrar ve böbrekte serum konsantrasyonlarının çok üzerinde bir konsantrasyona ulaşabilirler [30]. Bunlar yan etki potansiyellerinin yüksekliğine rağmen, üriner sistem enfeksiyonlarında tek başlarına etkindirler. Amikasin direncinin değişik çalışmalarda \%0-8 arasında değiştiği bildirilmektedir [31,32]. Bizim çalışmamızdaki değer ise \%7,6 olarak bu değerlerle uyumludur. Geçit ve ark. [23] gentamisin direncini $\% 21$, Gündüz ve ark. [17] \%30 olarak tespit etmişlerdir. Bizim bulgularımız da bu sonuçlarla uyumludur (\%21).

Karbapenem grubu antibiyotiklerden olan imipeneme karşı direnç hala düşüktür. Geçit ve ark. [23] direnç oranlarını \%0, Cebe ve ark. [18] \%0,8 olarak bulmuşlardır. Bizim çalışmamızda da imipeneme direnç saptanmamıştır. Bu ilaçların parenteral kullanılıyor olması kullanımını kisıtlamaktadır.

Nitrofurantoin, üriner sistem enfeksiyonlarının ampirik tedavisinde sik kullanılan antibiyotiklerdendir. Köksaldı Motor ve ark. [33] yaptıkları çalışmada nitrofurantoin direncini \%3; Tekin ve ark. [24] E. coli'lerde \%8,2; Cebe ve ark. [18] E. coli' de \%6,8, $K$. pneumonia' da \%50, P. mirabiliste \%60; Kibar ve ark. [19] \% 14 olarak tespit etmişlerdir. Bizim sonuçlarımız da bu değerlerle uyumlu bulunmuştur.

Çalışmamızda izole edilen bakteriler türlerine göre sıralandığında, E. coli'den sonra enterokoklar ve KNS gelmektedir. (Tablo-1). Kibar ve ark. [19] da ikinci siklıkla (\% 19) enterokok ürediğini gözlemlemişlerdir. Yurtdışında yapılan bazı çalışmalarda da \%8,5 [34] ve \%14 [20] gibi değerler bildirilmiştir. Bizim bulgularımız da \% 11 ile bu değerler arasında bulunmuştur. Enterokoklarda vankomisin direnci önemli bir problem olarak karşımıza çıkmaktadır. Vankomisine dirençli enterokoklardaki artış tedavide sıkıntılar yaşanmasına neden olmaktadır. Yapılan çalışmalarda \%1-4 arasında oranlar [19,20, 35] bildirilmiştir. Bizim oranımız bu değerlerden yüksektir. Bakteri sayısı az olduğu için de 2 tane dirençli olarak değerlendirilen suş bile yüksek bir orana tekabül etmektedir. Bakteri sayısının çok daha fazla olduğu çalışmalarla bu bulgu netleşecektir. Ayrıca elektronik Mc Farland okuyucu cihaz bulunmadığından bu Mc Farland ayarları çıplak gözle hazır solüsyonla karşılaştırılarak yapılmaktadır. Bundan dolayı da yüksek Mc Farland değerine sahip bir solüsyon hazırlanıp antibiyogram için kullanılmış olabilir. Vankomisine dirençli olarak değerlendirilen enterokoklara herhangi bir doğrulama testinin yapılamamış olmas1 da çalışmanın eksik kalan bir yönüdür. Enterokoklarda eritromisinle penisiline direnç de oldukça yüksek oranlarda tespit edilmiştir.

Stafilokoklarda metisilin direnci de önemli bir problemdir. Metisilin direncinde betalaktam antibiyotikler devre dişı kalmakta ve bu da tedavide güçlüğe yol açmaktadır. Stafilokokların tamamını göz önünde bulundurduğumuzda metisiline direnç oranımız \%66 olarak görünmektedir. Yurdumuzda yapılan çalışmalarda da benzer oranlar bildirilmiştir. [19, 21]. Stafilokoklarda eritromisine direncin de oldukça yüksek olduğu görülmektedir.

Çalışmamızda üreyen bazı bakterilerin sayıları az olduğu için bölgesel direnç paternini tam olarak yansitmayabilir. Ancak bu bilgiler hastanemizden bu konuyla ilgili olarak gönderilen ilk veriler olduğundan bir fikir vermeye yardımı olabileceğini düşünmekteyiz. Daha net sonuçların ortaya çıkması için geniş serileri kapsayan çalışmalara gerek duyulmaktadir.

Sonuç olarak, üriner sistem enfeksiyonlarında görülen antimikrobiyal direnç, yaşamın ilk yıllarında dahi önemli bir sorun oluşturmaya başlamıştır. Pediatrik üriner sistem enfeksiyonlarının tedavisinde ampirik antibiyotik kullanımında bölgesel, eğer elde veri varsa lokal direnç paternleri mutlaka göz önünde bulundurulmalıdır. Antibiyogram sonucu alındıktan sonra bu verilere dayanılarak tedavi şeması gözden geçirilmeli ve eğer dar spekturumlu ilaçlarla hasta tedavi edilebilecekse geniş spekturumlu ilaçlardan vazgeçilerek bunlar daha ciddi enfeksiyonlar için düşünülmelidir. 


\section{Kaynaklar}

1. Bagga A. Urinary tract infections: evaluation and treatment. Indian J Pediatr 2001; 68(Suppl 3): 40-5.

2. Jodal U. The natural history of bacteriuria in childhood. Infect Dis Clin North Am 1987; 1: 713-29.

3. Elder JS. Urologic disorders in infants and children. In: Behrman RE, Kliegman RM, Jenson HB (eds). Nelson textbook of pediatrics, 17th edition. Philadelphia: WB Saunders; 2004; pp: 1785-89.

4. Sirin A, Emre S, Alpay H, Nayır A, Bilge I, Tanman F. Etiology of chronic renal failure in Turkish children. Pediatr Nephrol 1995; 9: 549-52.

5. Krasinski KM. Urinary tract infections. In: Katz SL, Gershon AA, Wilfert CM (eds). Krugman's Infectious Disease of Children 9th Edition. St Louis: CV Mosby 1989; pp: 605-19.

6. Gonzales R. Urologic disorders in infants and children. In: Behrman RE, Kliegman RM, Jenson HB (eds). Nelson Textbook of Pediatrics. 16th edition. Philadelphia: WB Saunders Company; 2000; pp: 1528-32.

7. Lipsky BA. Urinary tract infections in men. Epidemiology, pathophysiology, diagnosis, and treatment. Ann Intern Med 1989; 110: 138-50.

8. Malhotra SM, Kennedy WA 2nd. Urinary tract infections in children: treatment. Urol Clin North Am 2004; 31: 527-34.

9. Larcombe J. Urinary tract infection in children. BMJ 1999; 319:1173-5.

10. Uyanık MH, Hanc1 H, Yazg1 H. Üriner sistem infeksiyonlarından soyutlanan toplum kökenli Escherichia coli suşlarına fosfomisin trometamolün ve bazı antibiyotiklerin in-vitro etkinliği. ANKEM Derg 2009; 23: 172-6.

11. Özçakar ZB, Yalçınkaya F. İdrar yolu enfeksiyonları. Türkiye Klinikleri J Pediatr 2007; 3: 99-104.

12. Prais D, Straussberg R, Avitzur Y, Nussinovitch M, Harel L, Amir J. Bacterial susceptibility to oral antibiotics in community acquired urinary tract infection. Arch Dis Child 2003; 88: 215-18.

13. Clinical and Laboratory Standards Institute. Performance standards for antimicrobial testing: Twenty-First Informational Supplement 2011(31): M100S21. Clinical and Laboratory Standards Institute, Wayne, PA.

14. Özsüt H. İdrar yolu infeksiyonları, Topçu AW, Söyletir G, Doğanay M: İnfeksiyon Hastalıkları ve Mikrobiyolojisi, Cilt 1: Sistemlere Göre İnfeksiyonlar kitabında İstanbul: Nobel Tıp Kitapevleri 2002; s: 1059-64.

15. Sobel JD, Kaye D. Urinary tract infections. In: Mandell GL, Bennet JE, Dolin R (eds): Principles and Practice of Infectious Diseases. 7th edition. Philadelphia: Churchill Livingstone; 2010; pp: 957-84.

16. Emre S: Üriner sistem enfeksiyonları. Olcay N (ed): Pediatri, 3. baskı kitabında İstanbul: Nobel Tip Kitabevleri; 2002; s: 1203-8.

17. Gündüz T, Tosun S, Demirel MM, Ertan Pelin. Çocuklarda idrar yolu enfeksiyonlarında antibiyotik direnci: Beş yıllık sonuçlar. Pam Tıp Dergisi 2008; 1: 87-90.

18. Cebe A, Ayvaz A, Yıldız N, Çetinkaya S. Sivas ilinde çocukluk çağı idrar yolu enfeksiyonlarında idrar kültür sonuçları: İlk tedavi seçimi nasıl olmalıdır? Van T1p Dergisi 2008; 15: 7-12.

19. Kibar F, Yaman A, Dündar İH. İdrar örneklerinden izole edilen bakteriler ve antibiyotiklere Duyarlıl1kları. Türk Mikrobiyol Cem Derg 2004; 34: 162-70.

20. Karlowsky JA, Lagacé-Wiens PR, Simner PJ, DeCorby MR, Adam HJ, Walkty A, Hoban DJ, Zhanel GG. Antimicrobial resistance in urinary tract pathogens in Canada from 2007 to 2009: CANWARD surveillance study. Antimicrob Agents Chemother 2011; 55: 3169-75.

21. Yıldırım M, Şahin İ, Gülcan A, Özdemir D, Küçükbayrak A, Uzun H, Kaya D. Antimicrobial susceptibility and uropathogens isolated from children and adults 
with community- acquired urinary tract infections. Turkiye Klinikleri J Med Sci 2010; 30: 533-8.

22. Üstün C, Demir YS, Demir S, Demirören S, Kurtoğlu MG. Pediatrik yaş grubu toplum kökenli üriner sistem infeksiyonlarından izole edilen Escherichia coli ve Klebsiella spp. suşlarının in-vitro antibiyotik direnci. ANKEM Derg 2009; 23: 155-60.

23. Geçit İ, Benli E, Beytur A, Keleş İ, Korulmaz A. Bingöl yöresinde çocuk hastalarda Escherichia coli direnci. J Clin Anal Med 2012; 3: 271-3.

24. Tekin A, Dal T, Deveci Ö, Tekin R, Bozdağ H, Özekinci T. In vitro efficacy of nitrofurantoin and some antibiotics in Escherichia coli strains 1solated from urine cultures. The New Journal of Medicine 2012; 29: 88-91.

25. Judith A, O'Donnell, Steven P, Abrutyn E. Selecting drug regimens for urinary tract infections: Current recommendations. Infect Med 2002; 19: 14-22.

26. Stamm WE, Hooton TM. Management of urinary tract infections in adults. N Engl J Med 1993; 329: 1328-34.

27. Salduz ZIYY, Yiğit Ö. İdrar yolu enfeksiyonlu çocuklardan izole edilen bakterilerin antibiyotik duyarlılıkları. J Pediatr Inf 2010; 4: 138-42.

28. Yaşar KK, Pehlivanoğlu F, Şengöz G. Pediyatrik yaş grubunda idrar yolu infekslyonlarında gram negatif mikroorganizmaların dağılımı ve antibiyotik direnci. Zeynep Kamil Tıp Bülteni 2010; 41: 137-41.

29. Kayaş L, Yolbaş İ, Ece A, Kayaş Y, Balık H, Kocamaz H. Causative agents and antibiotic susceptibilities in children with urinary tract infection. JMID 2011; 1 : 17-21.

30. Çolak H. Üst üriner sistem infeksiyonları: Uzun Ö, Ünal S. Güncel bilgiler işığında infeksiyon hastalıkları kitabında, Cilt 1, Ankara; Bilimsel Tıp Yayınevi 2001; s: 343-55.

31. Kaya D, Öksüz Ş, Kaya E. Üriner sistem enfeksiyonu etkeni olan E. coli suşlarının bazı antibiyotiklere duyarlılıklarının araştırılması. AİBÜ Düzce Tıp Fak Derg 2000; 1: 43-6.

32. Tosun SY, Demirel MM, Ertan P, Aksu S. Çocuklara ait idrar örneklerinden izole edilen bakterilerin antibiyotik duyarlılıkları. Türkiye Klin Pediatr Derg 2004; 13: 59-62.

33. Köksaldı Motor V, Tutanç M, Arıca V, Arıca S, Ay B. Üropatojen Escherichia coli suşlarının üriner sistem infeksiyonlarının tedavisinde sık kullanılan antibakteriyel ajanlara duyarlılıklar1. ANKEM Derg 2010; 24: 198-201.

34. Hryniewicz K, Szczypa K, Sulikowska A, Jankowski K, Betlejewska K, Hryniewicz W. Antibiotic susceptibility of bacterial strains isolated from urinary tract infections in Poland. J Antimicrob Chemother 2001; 47: 773.

35. Barros M, Martinelli R, Rocha H. Enterococcal urinary tract infections in a university hospital: clinical studies. Braz J Infect Dis 2009; 13: 294-6. 